\title{
EUROPEAN INVASION IN PROGRESS: MYRIOPHYLLUM HETEROPHYLLUM MICHX. (HALORAGACEAE) IN CROATIA
}

\author{
Nenad Jasprica ${ }^{1}$, Andelka Lasić ${ }^{2}$, Dubravka Hafner ${ }^{3}$ \\ \& Ana Bratoš Cetinić ${ }^{4}$ \\ ${ }^{1 *}$ University of Dubrovnik, Institute for Marine and Coastal Research, P.O. Box 83, \\ HR-20000 Dubrovnik, Croatia \\ ${ }^{2}$ Faculty of Natural Sciences and Education, University of Mostar, BiH-88000 Mostar, \\ Bosnia and Herzegovina \\ ${ }^{3}$ Bartulovići 4, HR-20357 Blace, Croatia \\ ${ }^{4}$ Department of Aquaculture, University of Dubrovnik, Ćira Carića 4, \\ HR-20000 Dubrovnik, Croatia
}

Jasprica, N., Lasić, A., Hafner, D. \& Bratoš Cetinić, A.: European invasion in progress: Myriophyllum heterophyllum Michx. (Haloragaceae) in Croatia. Nat. Croat., Vol. 26, No. 1, 99-103, 2017, Zagreb.

In Europe, Myriophyllum heterophyllum Michx. (Haloragaceae) has had the status of invasive species in freshwater ecosystems since 2012. During phytosociological research in the Neretva River Delta in July 2016, we noted a high coverage of species Myriophyllum heterophyllum within vegetation of rooted leaf-floating macrophytes of the Nymphaeion albae Oberd. 1957 alliance (the order Potamogetonetalia Koch 1926). In this paper, alongside the finding of the new locality with M. heterophyllum in Croatia, its phytosociology is reported.

Keywords: alien taxon, freshwater ecosystems, the Nymphaeion albae alliance, the Neretva River delta, Croatia, NE Mediterranean

Jasprica, N., Lasić, A., Hafner, D. \& Bratoš Cetinić, A.: Myriophyllum heterophyllum Michx. (Haloragaceae) u Hrvatskoj. Nat. Croat., Vol. 26, No. 1, 99-103, 2017, Zagreb.

Sjevernoamerička vrsta Myriophyllum heterophyllum Michx. (Haloragaceae) u Europi ima status invazivne vrste od 2012. godine. Tijekom fitocenoloških istraživanja u delti Neretve u srpnju 2016., utvrdili smo visoku pokrovnost vrste Myriophyllum heterophyllum u vegetaciji zakorijenjenih makrofita sveze Nymphaeion albae Oberd. 1957 (Potamogetonetalia Koch 1926). Prema dosadašnjim podacima, to je drugi nalaz te vrste u Hrvatskoj.

Ključne riječi: alohtona vrsta, slatkovodni ekosustavi, sveza Nymphaeion albae, delta Neretve, Hrvatska, SI Sredozemlje

\section{INTRODUCTION}

Myriophyllum heterophyllum is an aquatic plant native to the eastern United States, where it often forms dense stands (BRown et al., 2014). The species is commonly used in aquaria and for ornamental purposes in ponds. It was included in the European and

\footnotetext{
* Corresponding author (e-mail: nenad.jasprica@unidu.hr)
} 
Mediterranean Plant Protection Organization (EPPO) alert list in 2009 and subsequently transferred to the List of Invasive Alien Plants in 2012 (EPPO, 2009, 2014). It has shown a fast rate of spread in western parts of Europe (HuSSNER, 2012; LAFONTAINE et al., 2013, etc.).

Myriophyllum heterophyllum is present as an alien species in nine European countries: Austria, Belgium, France, Germany, Hungary, the Netherlands, Spain, Switzerland and the United Kingdom (Hussner, 2012; EPPO, 2015; Brundu, 2015). Throughout the world it is invasive in southern China (Yu et al., 2003) and Guatemala in Central America (EPPO, 2016). In addition, according to the Euro+Med Plantbase (Euro+Med, 2006-2016) it was reported only for the United Kingdom, Austria, Germany, Switzerland and Spain. According to EPPO (2016), no presence of the taxon in SE Europe has yet been found (Fig. 1).

In fact, the presence of the taxon in Croatia has been overlooked and not included in EPPO. Actually, it was found for the first time in Croatia on the island of Krk, northeastern Adriatic, in the small Lake Ponikve in 2000 (STARmüHLER, 2009). In this study, we report the most southern Croatian locality with Myriophyllum heterophyllum and shortly describe its phytosociology.

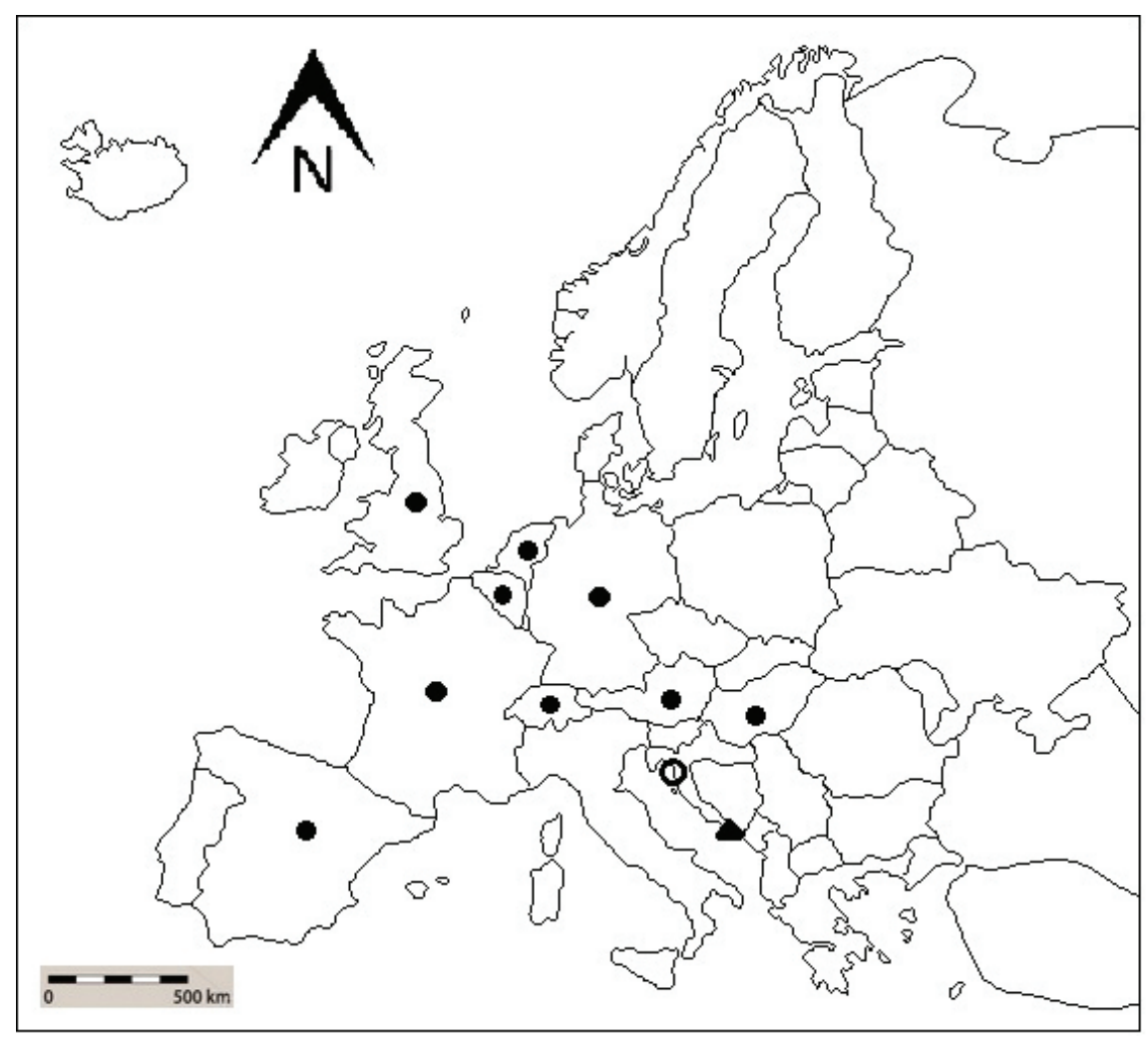

Fig. 1. European countries where Myriophyllum heterophyllum Michx. occurs (•). In Croatia, symbols indicate its presence from a previously known locality $(\mathrm{O})$ and that found in this study $(\boldsymbol{\Delta})$. 


\section{MATERIALS AND METHODS}

\section{Study area}

From a biogeographic viewpoint, the study area is included in the Epiro-Dalmatian sector of the Adriatic province (Rivas-Martínez et al., 2004). The Neretva River delta consists of numerous channels that empty into the Eastern Adriatic Sea and several lakes, each of which is a karstic crypto-depression. Looking downstream, Lake Desne is located in the NW part of the delta i.e. on the right side of the Neretva River. Lake water originates mostly from underground karstic springs. It is oligotrophic, poorly mineralized, generally contains a small quantity of dissolved carbon dioxide (as bicarbonate), and often is turbid (JASPRICA \& HAFNER, 2005). Additional details on the lake's trophic status and the study area, in general, are given by JASPRICA \& HAFNER (2005), and JASPRICA et al. (2005).

\section{Sampling and identification}

Surveys were conducted according to methodology described by LASIĆ \& JASPRICA (2016). This phytosociological relevé was carried out using the 7-grade scale of BRAUNBLANQUET (1964). In the Result and Discussion section, coverage values of the taxa in the relevé are indicated by symbols in the brackets. Myriophyllum heterophyllum was determined according to Wimmer (1997), Yu et al. (2003), BAiley (2007) and Lebreton (2013), etc., while other macrophytes were determined using the standard determination keys, books and guides (for details see JASPRICA \& Milović, 2016). "Chara globularis Thuillier group" was determined according to HaAs (1994) and Pukacz et al. (2011). Nomenclature of plant species follows the Euro+Med Plantbase (Euro+Med, 2006-2016). The syntaxonomic system proposed by Mucina et al. (2016) was followed. Myriophyllum heterophyl-

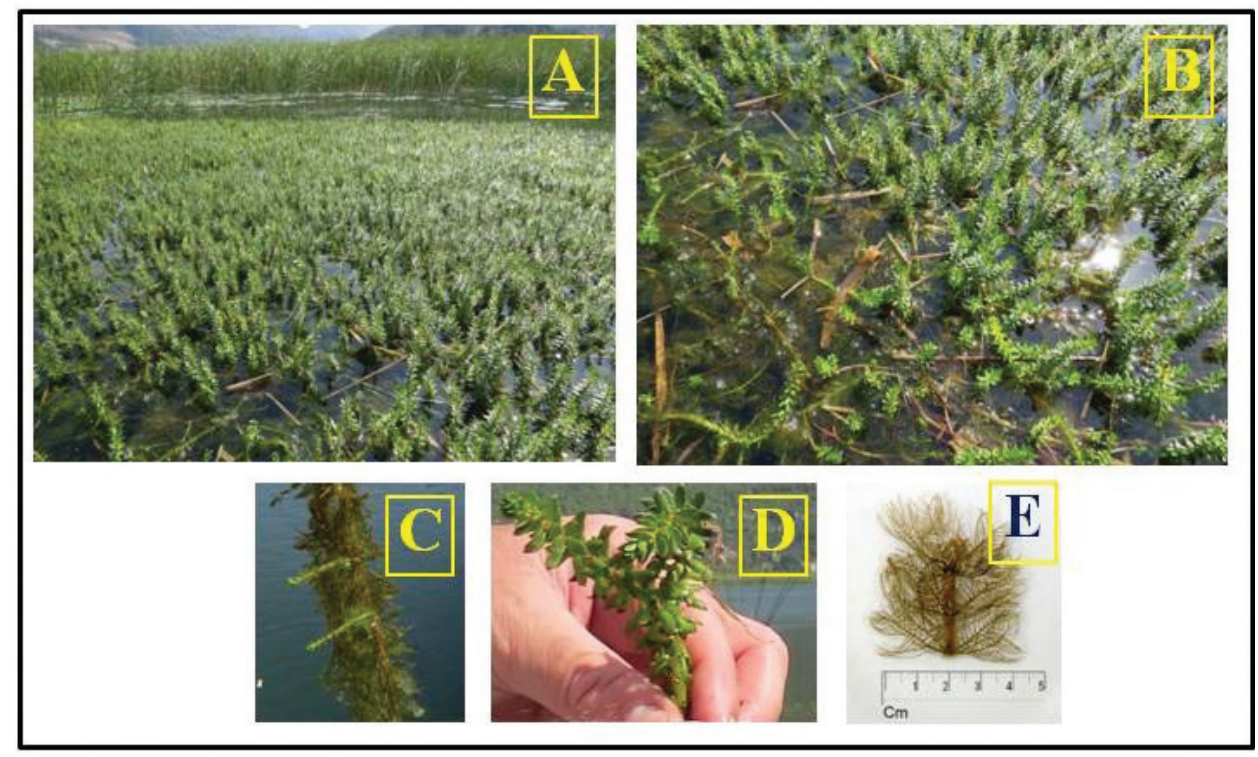

Fig. 2. Myriophyllum heterophyllum Michx. in submersed macrophyte community in the lower Neretva river Delta on July 26, 2016 (A), habitus (B), details on submerged and emergent leaves (C, D), submerged leaves (E). 
lum herbarium specimens are housed in the University of Dubrovnik, Institute for Marine and Coastal Research, Laboratory for Terrestrial Flora and Fauna, code NJNRD-2016-1; Leg. et det. N. Jasprica.

\section{RESULTS AND DISCUSSION}

Myriophyllum heterophyllum was found within vegetation of rooted leaf-floating macrophytes in Lake Desne $\left(43^{\circ} 03^{\prime} 35.9^{\prime \prime} \mathrm{N}, 17^{\circ} 31^{\prime} 08.45^{\prime \prime} \mathrm{E}\right)$ within the Nymphaeion albae Oberd. 1957 alliance and the Potamogetonetalia Koch 1926 order in July 2016 (Fig. 2). In our case, the community occurs in shallow (up to $1 \mathrm{~m}$ ), almost stagnant waters, and it covers a surface area of $25 \mathrm{~m}^{2}$. Similarly, Thum \& LenNon (2010) reported M. heterophyllum from "higher order" lakes characterized as large, low elevation systems with relatively high $\mathrm{pH}$, alkalinity and conductivity. The optimum temperature for $M$. heterophyllum is about $20^{\circ} \mathrm{C}$ (Hussner \& JAhns, 2015). According to StarmüHLer (2009), the taxon was found in a 3-10 $\mathrm{m}$ deep lake on the island of Krk, northern Adriatic.

The community described in this report is characterized by a carpet of large leaves and flowers of the species Myriophyllum heterophyllum (5), Nymphaea alba L. (1) and Nuphar lutea (L.) Sm. (+), as well as others like Najas marina L. $(+)$, Chara globularis group (+), Nitella sp. (+) and Schoenoplectus lacustris (L.) Palla (r). The community can be referred to the Nymphaeetum albae Vollmar 1947 [=Myriophyllo verticillati-Nupharetum lutei Koch 1926] association, but in this case, M. verticillatum is completely missing (cf. LAsić \& JASPRICA, 2016).

The species could inhabit the whole of Europe, except the Scandinavian tundra and taiga areas (EPPO, 2016). Climate change is likely to increase the ecologically suitable area. The risk of the species inhabiting additional countries is high as movement through irrigation and river systems acts to connect countries, facilitating spread regionally (BRUnel et al., 2010;_LAFONTAIne et al., 2013). Habitats within the endangered area include riparian systems, slow moving rivers, canals, irrigation canals, lakes, reservoirs and wetlands. The spread of $M$. heterophyllum occurs predominately via vegetative propagation. The spread may be accelerated by recreational activities in water bodies invaded by the weed (BRUNDu et al., 2013).

Our finding contributes to the knowledge of the chorology and ecology of M. heterophyllum, the floristic richness and vegetation diversity of Croatia, but also emphasizes the further spreading of newcomers to accommodating freshwater habitats.

\section{Acknowledgements}

We would like to thank the two anonymous reviewers for their helpful comments and the editors for their efforts in improving this report.

Received March 13, 2017

\section{REFERENCES}

BAILEY, J. E., 2007: Myriophyllum heterophyllum Michx. (Haloragaceae): control and vegetative reproduction in southwestern Maine. MSc Thesis. The University of Maine, USA. Electronic Teses and Dissertations. Paper 373. 38 pp.

Bouxin, G. \& LAmbinon, J., 1996: Deux xénophytes aquatiques nouveaux pour la Belgique, Myriophyllum heterophyllum et Lagarosiphon major, dans la Meuse a Lives-sur-Meuse (province de Namur). Natura Mosana 49, 94-97. 
Braun-Blanquet, J., 1964: Pflanzensoziologie. Grundzüge der Vegetationskunde. 3. New York, USA: Springer-Verlag.

Brown, R., Scribailo, R. W. \& Alix, M. S., 2014: Haloragaceae. Flora of North America, Provisional Publication. Flora of North America Association. May 28, 2014. Available at fna.huh.harvard.edu/files/ Haloragaceae.pdf [accessed 26 July 2014].

BRundu, G., 2015: Plant invaders in European and Mediterranean inlandwaters: profiles, distribution, and threats. Hydrobiologia 746, 61-79.

Brundu, G., Azzella, M. M. Blasi, C. Camarda, I. Iberite M. \& Celesti-Grapow, L., 2013: The silent invasion of Eichhornia crassipes (Mart.) Solms. in Italy. Plant Biosystems 147, 1120-1127.

Brunel, S., Schrader, G., Brundu, G. \& Fried, G., 2010: Emerging invasive alien plants for the Mediterranean Basin. Bulletin OEPP/EPPO Bulletin 40, 219-238.

EPPO, 2009: Myriophyllum heterophyllum (Haloragaceae) Watermil foil. Available at https:/www.eppo. int/INVASIVE_PLANTS/iap_list/Myriophyllum_heterophyllum.htm [last accessed March 15, 2015].

EPPO, 2014: PM 9/19 (1) Invasive alien aquatic plants. Bulletin OEPP/EPPO Bulletin 44, 457-471.

EPPO, 2015: Pest risk analysis for Myriophyllum heterophyllum. EPPO, Paris. Available at http://www.eppo. int/QUARANTINE/Pest_Risk_Analysis/PRA_intro.htm

EPPO, 2016: Myriophyllum heterophyllum Michaux. Bulletin OEPP/EPPO Bulletin 46, 20-24.

Euro+Med (2006-2016): Euro+Med PlantBase - the information resource for Euro-Mediterranean plant diversity. Available at http://ww2.bgbm.org/EuroPlusMed/ [last accessed December 24, 2016].

HAAs, J. N., 1994: First identification key for charophyte oospores from central Europe. European Journal of Phycology 29, 227-235.

Hussner, A., 2012: Alien aquatic plant species in European countries. Weed Research 52, 297-306.

Hussner, A. \& JAHns, P., 2015: European native Myriophyllum spicatum showed a higher HC03- use capacity than alien invasive Myriophyllum heterophyllum. Hydrobiologia 746, 171-182.

JASPRICA, N. \& HAfNer, D., 2005: Taxonomic composition and seasonality of diatoms in three Dinaric karstic lakes in Croatia. Limnologica 35, 304-319.

Jasprica, N., Hafner, D., Batistić, M. \& Kapetanović, T., 2005: Phytoplankton in three freshwater lakes in the Neretva River delta (Eastern Adriatic, NE Mediterranean). Nova Hedwigia 81, 37-54.

Lafontaine, R.-M., Beudels-Jamar, R.C., Delsinne, T. \& Robert, H., 2013: Risk analysis of the VariableWatermilfoil Myriophyllum heterophyllum Michaux. - Risk analysis report of non-native organisms in Belgium from the Royal Belgian Institute of Natural Sciences for the Federal Public Service Health, Food chain safety and Environment. 33 p.

LAsić, A. \& JAsprica, N., 2016: Vegetation diversity of the two Dinaric karstic rivers in Bosnia and Herzegovina. Biologia 71, 777-792.

Lebreton, A., 2013: Myriophyllum heterophyllum Michaux [Haloragaceae] en Haute-Vienne (Limousin, France), et situation de cette plante invasive en France et en Europe. Bulletin OEPP/EPPO Bulletin 43, 180-192.

Mucina, L., Bültmann, H. Dierssen, K. Theurillat, J.-P. Raus, T. Čarni, A. et al., 2016: Vegetation of Europe: hierarchical floristic classification system of vascular plant, bryophyte, lichen, and algal communities. Applied Vegetation Science 19 (Suppl. 1), 3-264.

Pukacz, A., PeŁechaty, M. \& Petrović, S., 2011. The use of morphometric characteristics in the identification of two morphologically similar charophytes: Chara globularis and Chara virgata. Biologia 66, 425-428.

Rivas-Martínez, S., Penas, A. \& Díaz, T.E., 2004: Bioclimatic \& Biogeographic Maps of Europe. Universityof León, Spain. Available at http://www.globalbioclimatics.org/form/maps.htm [last accessed on November 5, 2015].

Starmühler, W., 2009: Vorarbeiten zu einer „Flora von Istrien“, Teil XII. Carinthia II, 199./119., 553-600.

Thum, R. A. \& Lennon, J. T., 2010: Comparative ecological niche models predict the invasive spread of variable-leaf milfoil (Myriophyllum heterophyllum) and its potential impact on closely related native species. Biological Invasions 12, 133-143.

YU, L.Z., DAN, Y. \& Dong, W., 2003: Taxonomic revision of the genus Myriophyllum (Haloragaceae) in China. Rhodora 104, 396-421.

Wimmer, W., 1997: Myriophyllum heterophyllum Michaux in Lower Saxony and Bremen and determination key for the vegetative stage. Floristische Rundbriefe 31, 23-31. 